\title{
POSNER'S CURRICULUM ANALYSIS FRAMEWORK TOWARDS THE DEVELOPMENT OF PHILIPPINE MADRASAH EDUCATION
}

\author{
Abdul Haiy A. Sali \\ College of Graduate Studies and Teacher Education Research \\ Philippine Normal University \\ Taft Avenue, Manila, Philippines \\ (abdulhaiysali@gmail.com) \\ DOI: https://doi.org/10.22452/jati.vol26no1.8
}

\begin{abstract}
The madrasah education curriculum is imperative in the implementation of madrasah education in the Philippines. The importance of the curriculum processes and products as collection of work encompasses the significant involvement of key stakeholders in curriculum development. The purpose of this paper was to provide a detailed curriculum analysis of the Refined Elementary Madrasah Curriculum using Posner's curriculum analysis and its implication towards the development of Philippine madrasah education. The study employed a qualitative research design mainly through document analyses and key informant interviews of program implementers. Based on the analysis, the perspective of the curriculum is to provide appropriate and relevant educational opportunities within the context of accepted cultures, customs, traditions and interests of Muslim Filipino learners. In addition, there is an attempt to contextualise the learning goals of the Philippine classroom. However, some of the participants described the curriculum as relevant but not age-appropriate. In addition, as basic tenets in designing a curriculum, there were no specific learning activities elaborately explaining the instructional strategies and course resources. Also, there was no assessment task or evaluation explicitly incorporated in the curriculum. Conversely, the institutionalisation of the Madrasah Education Program (MEP) in public school provides an opportunity to develop and ensure access to quality and relevant education among Muslim learners. The results provide baseline data in understanding the curriculum and serve as an impetus for future curriculum development of madrasah education in the Philippines.
\end{abstract}

Keywords: Philippine madrasah education, curriculum development, ALIVE Program, the Philippines 


\section{Introduction}

The curriculum is an essential guide in implementing the Madrasah Education Program (MEP) in the Philippines. In its form, the educational objectives, core competencies, expected outcomes, and evaluation are embedded in the design (Ornstein \& Hunkins, 2018). On the other hand, the importance of the curriculum processes and products being used as a collection of work encompasses the significant involvement of learners, teachers, school staff, and community members. The products are very essential as it provides instructional decisions in the educative process. In general, the curriculum sums up the learner's experiences in making learning more relevant and appropriate. At present, madrasah teaches Islamic knowledge and is distinct in the context of architecture, organisation, instruction, learning, curriculum and funding sources (Kadi, 2006, as cited in Sabki \& Hardarker, 2013). The madrasah education implementation (Arsad, 2007; Boransing, 2006; Marasigan 2019a; Marasigan 2019b; Milligan, 2006; Rodriguez, 1986; Sali, 2020a; Sali, 2020b; Sali \& Ancho, 2021; Sali \& Marasigan, 2020; Solaiman, 2017) in the Philippines is multifaceted. The institutionalisation of Arabic Language and Islamic Values Education (ALIVE) program was made possible through a series of consultations and efforts of the government and Muslim intellectuals (Sali \& Marasigan, 2020, p. 204).

However, since its inception, there has been a dearth of professional literature on the implementation of ALIVE program in the Philippines (Sali, 2020a, 2020b; Sali \& Ancho, 2021; Sali \& Marasigan, 2020). In relation to curriculum, there were few studies previously undertaken by researchers significant to the implementation of MEP: Rodriguez (1986) in her study pointed out the essence of adopting MECS-Madrasah Reconciliatory Curriculum to harmonise the national basic education curriculum with madrasah schools. The said curriculum must be responsive to gainful employment as to not waste talents of the learners. The premise was to maximise contribution to the modernisation of the communities and attainment of national development plan.

In the course of development of the Philippine Madrasah Education, Nunag (1970) recommended the creation of Bureau of Private Schools to supervise the madaris and improve their academic standard to make it aligned with national goals. In addition, according to Rodriguez (1986), to improve and oversee the implementation, a centralised national governing and policy-making body was needed. Furthermore, the issuance of DepEd Order no. 51 s. 2004 (Standard Curriculum for Elementary Public Schools and Private Madaris) catapulted the aspiration of Muslim Filipinos for quality and relevant Islamic education in the country. In terms of strengthening MEP in public school, Arsad (2007) in her study 
entitled A framework for integration of Madrasah into the basic education sought adding Arabic Language and Islamic Studies in the curriculum and the dire need to integrate Muslim schema, concepts, values, and experiences into the framework were unprecedented.

However, the Muslim Education Initiative Review Final Report published in 2014 exemplified several recommendations on how to improve MEP implementation in terms of responsiveness, appropriateness, and relevance of the madrasah education curriculum. In particular, some of the challenges on the translation of the curriculum were: Asatidz or madrasah teachers as curriculum implementers were generally dependent on textbooks; based on the level 1 curriculum mapping, the Arabic language subject cannot be "considered completely relevant" (Muslim Education Initiative Review Final Report, 2014, p. 195); and considering the results of level 4 curriculum mapping, Islamic values is "somewhat relevant but not appropriate" (Muslim Education Initiative Review Final Report, 2014, p. 196). In an effort to analyse the Refined Elementary Madrasah Curriculum (REMC) through systematic document analysis and the experiences of MEP implementers, this study attempts to provide essential information through a qualitative inquiry that allows in-depth analysis on the understanding of REMC anchored to Posner's Curriculum Analysis (2004) Framework. The Posner's Curriculum analysis provides an in-depth understanding of the curriculum's creation, beliefs, assumptions, teaching practices, strengths and weaknesses, among others. The results of the study provide a general overview of the $\mathrm{c}$ as triangulated to the responses of the program implementers.

In the professional literature, there is a scarcity of research study on the grassroots implementation of madrasah education in the Philippines. The significant development of Philippine madrasah education is contingent on the grassroots implementation (Sali \& Marasigan, 2020; Sali \& Ancho, 2021). The importance of curriculum as a guide and its implication to the over-all development of madrasah education is unprecedented. Hence, the study seeks to analyse the Refined Elementary Madrasah Curriculum implemented in selected ALIVE schools in Quezon City. This study will specifically answer the following question:

How is REMC enacted and its implications to the development of madrasah education in terms of the followings: curriculum documentation and origins; curriculum in use; curriculum proper; and curriculum critique? 


\section{Literature Review and Conceptual Framework}

\section{On Inclusive Education and Multicultural Curriculum}

In 2000, the United Nations crafted the 8 Millennium Development Goals (MDGs) in order to reaffirm the necessity of accessible universal primary education. In 2015, the Millennium Development Goals implementation among participating countries was assessed including the Philippines. However, the progress had been uneven and improvements were often intermittent among participating countries. Consequently, the world leaders agreed to advance a wide-ranging and inclusive framework for sustainable development. The same year, the 17 Sustainable Development Goals (SDGs) were formulated to ensure continuous access to quality, inclusive, and relevant education by 2030 .

A multicultural curriculum design (Demir \& Yurdakul, 2015; Guo \& Jamal, 2007; Milligan, 2006) should promote aims on raising democratic individuals with awareness and acceptance of learners' differences, respect to human rights, and acceptance of other cultures. The premise of tailor-fitting traditional curricula into multicultural structure prevents learners from being marginalised in the education setting. According to Lingard (2005), the assumption of quality pedagogy as a method to inculcate important social justice issue in education is appropriate for the contemporary post-modern globalised world. To enable quality learning experience in the educative process, the teachers should be empowered to enable relevant experiences particularly those 'at-risk' learners who are socially, economically and culturally disadvantaged. This enables inclusive education to flourish as a mechanism to improve inequitable access to education in the world.

In religious education, there are two concepts imperative to inclusive education: the confessional religious education; and the non-confessional religious education (Puskás \& Andersson, 2019). The former aims to produce religious commitment to only one religion while the latter aims to integrate religion through religious content in various subjects such as history, philosophy, and ethics, among others. Furthermore, to Miedema (2006), religious education should not unilaterally be conceptualised in a knowledge-based or cognitive terms because religious citizenship is essential for a child's whole personal development. On the other hand, the non-confessional religious education teaches respect, understanding and acceptance for everyone regardless of their religious or philosophical beliefs. 


\section{On the Development of Madrasah Education in the Philippines}

Muslims have their own cultural identity. As such, the inclusivity of education for Muslim Filipino learner has a pivotal role in the development and growth of education - as a fundamental philosophy throughout UNESCO's programmes. Remarkably, Inclusive Education addresses issues of marginalisation and exclusion (Peters, 2003).

Despite the efforts of the Philippine government to improve madrasah education, in a contemporary society, emerging educational challenges are inevitable. Abu Bakar (2018) argued the need to develop sound and moral spiritual citizens in a globalised world. In an attempt to create a pedagogical framework responsive to the current needs, Abdullah (2018) emphasised the necessity for hermeneutics of Islamic education. The emerging educational landscape provides a clear perspective of revisiting program and policies relevant to madrasah education in the Philippines (Sali \& Ancho, 2021). With the advent of the different reform strategies and approaches in curriculum development, the Department of Education (DepEd) leads the pacing of institutional reforms among the learners of the $21^{\text {st }}$ century. For instance, the DepEd Order No. 41, s. 2017 provides appropriate and relevant educational opportunities to Muslim Filipinos within the context of accepted cultures, customs, traditions and interests. In 2010, a comprehensive curriculum "institutionalising of Madrasah Education Program (MEP) was initiated in public schools to achieve inclusivity and quality education for all" (Sali \& Marasigan, 2020, p. 202).

\section{On Madrasah Education Curriculum of ALIVE Program}

The implementation of ALIVE program in basic education can be considered part of the Islamisation (Milligan, 2006) of education in the Philippines. The premise of inclusive education to Muslim Filipino learners provides educational opportunity for every learner despite different ethnic and religious backgrounds. The ALIVE program enabled institutionalisation of MEP in public schools. It became an integral part of the government's mandate to provide comprehensive educational program to Muslim Filipinos (Caballero-Anthony, 2007). The ALIVE program provides appropriate and relevant educational opportunities within the context of accepted cultures, customs, traditions and interests (DepEd Order No. 41, s. 2017). The Refined Elementary Madrasah Curriculum (REMC) for ALIVE program adds two subjects to the regular basic education curriculum: Arabic Language; and Islamic Values (Refined Elementary Madrasah Curriculum, 2010). In public schools, 
the Arabic language is usually taught three times a week for 40 minutes per session and Islamic values education for two times a week.

However, the results of Review Report on the Three Years Implementation of ALIVE Program (2008) identified challenges on the existing curricular structure, such as class scheduling and time allotment. The results of the Muslim Education Initiative Review Final Report (2014) illustrated several challenges on the responsiveness, appropriateness and relevance (RAR) on REMC. Based on the level 1 curriculum mapping, the Arabic language subject cannot be "considered completely relevant" (p. 195). Accordingly, the RAR goals statements are just implied in the curricular goals. This means the following aspirations are achieved if the "primary goals" (Muslim Education Initiative Review Final Report, 2014, p. 195) are achieved to consider the following: cultivates spirituality through reading, knowing, and living the lessons learned from the Qur-an; aims towards improved mental, physical, social well-being of the learners; makes Muslims leaners competitive in Arabic language; and helps Muslim learners work in Arabic country for better social and economic condition. Furthermore, considering the results of level 4 curriculum mapping, Islamic values is somewhat relevant but not appropriate. For instance, promotion of peace is clearly stated in "the curricular goals and terminal objectives but the listing of contents does not explicitly include Islamic values of the achievement of peace" (Muslim Education Initiative Review Final Report, 2014, p. 196).

In a qualitative study conducted by Sali and Marasigan (2020), the Asatidz as curriculum implementers were aware of the existence of REMC. However, it was noted that the Asatidz had high dependency on textbooks and didactic in inculcating values formation (Muslim Education Initiative Review Final Report, 2014). Furthermore, despite showing diversity in teaching practices and pedagogical praxis (Sali, 2020a) based on the actual classroom observation, a significant number of the Asatidz showed disconnect between the lesson objective and the formative assessment chosen for evaluation. Considerably, a significant number of madrasah teachers hired to implement the ALIVE program were high school graduates in secular education. However, the Asatidz are expected to be curriculum planners, designers, implementers and evaluators with awareness of pedagogical practices and content knowledge just like the regular teachers (Sali \& Marasigan, 2020). 


\section{Conceptual Framework}

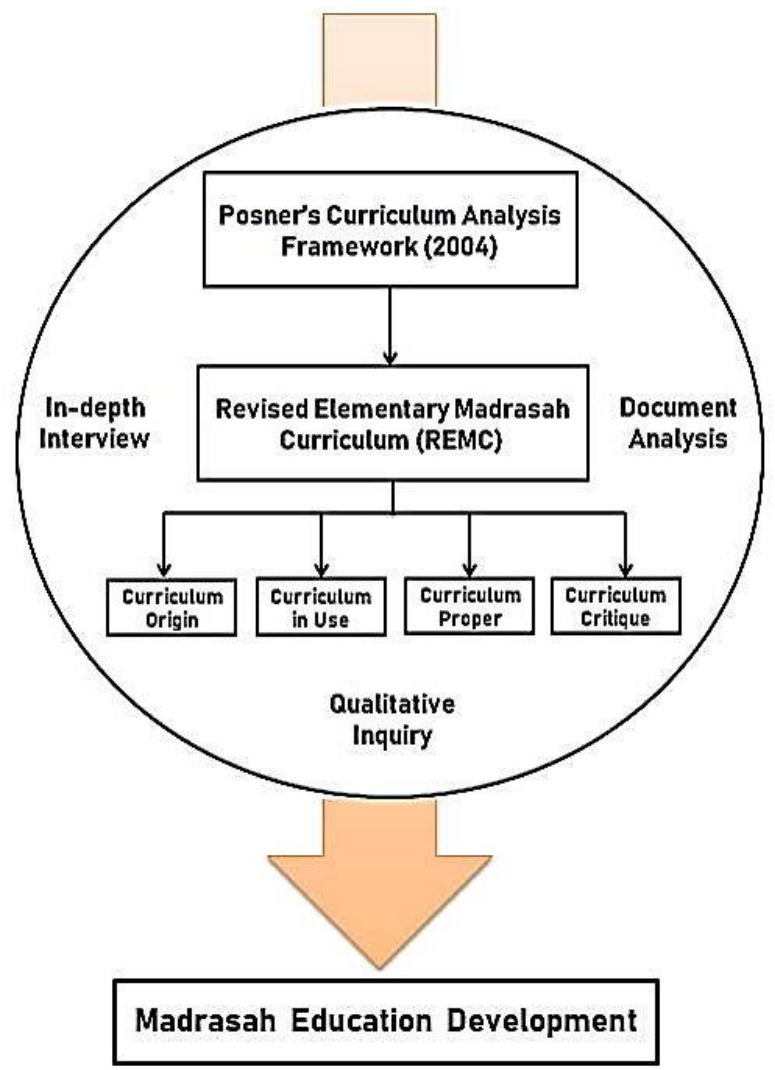

Figure 1: Conceptual Framework

This framework for the current investigation is anchored to Posner's Curriculum Analysis Framework (2004). The conceptual framework will examine and analyse the Refined Elementary Madrasah Curriculum and its implications to the development of madrasah education as implemented in the Arabic Language and Islamic Values Education schools in the Philippines. In this study, the conceptual flow will be analysed to examine the important relationships and salient responses specifically answering the following questions on: curriculum documentation and origins; curriculum in use; curriculum proper; and curriculum critique. The analysis of a wide range of research approaches in terms of their key questions posits "perspective to view the field of curriculum as a whole" (Posner, 1989, p. 340). In addition, a qualitative inquiry through key informant interviews (KIIs) will be initiated for corroboration of data. 


\section{Methodology}

This study used qualitative research design where the author adopted document analysis and key informant interviews (KIIs). In general, the document analyses were initiated to answer the following questions as adopted from Posner's Curriculum Analysis (2004): curriculum documentation and origins; curriculum in use; curriculum proper; and curriculum critique. In addition, the inquiry was anchored on the set of categories with set of questions (Posner, 2004) useful in describing and sorting assumptions on the curriculum. The responses from the research participants through interview were utilised to corroborate the findings of the document analysis. The participants of the study were: one Administrator; three ALIVE Coordinators; and four Asatidz from selected ALIVE public schools in Quezon City, Metro Manila in National Capital Region. The main document used was the Refined Elementary Madrasah Curriculum as the focus of the study. The following salient documents were also examined: DepEd Order (DO) No. 41, s. (Department of Education, the Philippines, 2017), Policy Guidelines on Madrasah Education in the K to12 Curriculum; DepEd Order (DO) No. 40, s. (Department of Education, the Philippines, 2011), Amendment to DO No. 51, s. 2004, or the Standard Curriculum for Elementary Public Schools and Private Madaris; Review Report on the Three Years Implementation of ALIVE Program published in 2008; and Muslim Education Initiative Review Final Report published in 2014.

A non-probability purposive sampling was selected. The participants, particularly the Asatidz, have at least two years of service and teaching experience on implementing the program. In addition, administrator and madrasah coordinators have at least rendered a year of service in the implementation of MEP. Lastly, participants who were willing to be part of the study were considered. The participants' consent was also initiated. The table represents demographic data of the eight participants based on the questionnaires. For the Asatidz, the average years of service in the implementation of ALIVE program were 10 years. The study employed the validated semi-structured interview. Furthermore, triangulation (Creswell, 1998) method of semi-structured interviews and other professional literature were employed. Thematic analysis of the data (Merriam, 2009) was conducted through 20-30 minutes interviews which were audio-taped. This study was limited to three ALIVE schools and the sample size of eight participants during the course of the study. 
Table 1: Basic Profile of the Participants

\begin{tabular}{|c|c|c|c|c|c|}
\hline Participant & Sex & $\begin{array}{l}\text { Length of } \\
\text { Service } \\
\text { (years) }\end{array}$ & $\begin{array}{c}\text { Highest } \\
\text { Educational } \\
\text { Attainment } \\
\text { (Secular) }\end{array}$ & $\begin{array}{c}\text { Highest } \\
\text { Educational } \\
\text { Attainment } \\
\text { (Non-Secular) }\end{array}$ & $\begin{array}{c}\text { Previous } \\
\text { Teaching } \\
\text { Experience }\end{array}$ \\
\hline P1 & Male & 10 & College Graduate & Thanawi & Yes \\
\hline P2 & Male & 8 & $\begin{array}{c}\text { High School } \\
\text { Graduate }\end{array}$ & Thanawi & Yes \\
\hline P3 & Female & 10 & College Graduate & Kulliyah & Yes \\
\hline $\mathrm{P} 4$ & Male & 13 & College Graduate & Thanawi & Yes \\
\hline P5 & Female & 20 & $\begin{array}{l}\text { Doctorate } \\
\text { Graduate }\end{array}$ & - & Yes \\
\hline P6 & Female & 20 & College Graduate & - & Yes \\
\hline P7 & Female & 14 & $\begin{array}{l}\text { Master's } \\
\text { Graduate }\end{array}$ & - & Yes \\
\hline P8 & Female & 23 & College Graduate & - & Yes \\
\hline
\end{tabular}

Note: Thanawi=High School; Kulliyah=College.

\section{Results and Discussion}

The study employed qualitative research design. In general, the document analyses were initiated to answer the following questions as adopted from Posner's Curriculum Analysis (2004) and its implications to the development of madrasah education: curriculum documentation and origins; curriculum in use; curriculum proper; and curriculum critique. The inquiry was anchored on the set of categories with set of questions (Posner, 2004) useful in describing and sorting assumptions on the curriculum. Also, the responses from the research participants through interview were utilised to corroborate the findings of the document analysis. 


\section{Curriculum Documentation and Origins}

Posner first directed the analyst to identify the human dimensions on the creation of the curriculum. In this analysis, the conceptions and motives of the developers were explored with emphasis on viewing curriculum as a product of various dialogues among the stakeholders. The Philippines despite predominantly a Catholic nation, houses are around six million Muslims comprising almost $6 \%$ of the national population (Philippine Statistical Authority, 2015). Muslims have their own cultural identity and a common history (Institute for Autonomy and Governance, 2019). In the Philippines as early as $14^{\text {th }}$ century, Islamic influence in education already existed (Milligan, 2006) even before the Spanish colonisation. Accounts by American colonial officials described a panditas school - a small group of boys studying Islam under the tutelage of a local learned Muslim (Milligan, 2006). Despite the rich tradition of Islamic education in the past, the colonial and post-colonial experience were 'sought to create cohesive national identity without careful consideration of religious, political, and cultural biases' (Sali \& Marasigan, 2020, p. 202). In 1935, in preparation for independence, the commonwealth government sought to create a unified Filipino identity by investing on educational policies. The government's initiative for cultural homogeneity inevitably inculcated ethno-religious conflict among Muslim-Filipinos (Milligan, 2005). However, the early Muslim-Filipinos were able to maintain their own educational system, which started as Qur-anic schools for young children and later became an established institution for learning or madrasah.

In the 1950s to 1960s, the dawn of transnational dawa'ah movement in the Philippines created a growing network of madaris. The former President Ferdinand Marcos issued Letter of Instruction No. 71-A allowing the use of Arabic as a medium of instruction in schools. In addition the Proclamation No. 1628, Letter of Instruction No, 1221, and Presidential Decree No. 6-A or the 'Education Development Decree of 1972', were issued to enhance human resources and preservation of the country's Islamic heritage. In addition, to harmonise the national basic education curriculum with the madrasah schools, Rodriguez (1986), recommended adopting the MECS-Madrasah Reconciliatory Curriculum. The said curriculum would incorporate commonalities of the different madaris curricula implemented in the country. Furthermore, the 1976 Tripoli Agreement between the Moro National Liberation Front (MNLF) and the government of the Philippines became an important milestone for the institutionalisation and mainstreaming of MEP in the country.

In 1995, The World Declaration on Education for All and the Framework for Action to Meet Basic Learning Needs were adopted in Jomtien, Thailand. This 
initiative reiterated the commitment of the participating countries to prioritise education as a fundamental human right. In 2000, at the World Education Forum in Dakar, Senegal, the international community reaffirmed its commitment to achieve Education for All, this time by 2015. Thus, the United Nations crafted the 8 Millennium Development Goals (MDGs) in order to reaffirm the necessity of accessible universal primary education and later formulated a more comprehensive Sustainable Development Goals (SDGs) to include a more specific target in ensuring access to quality, inclusive, and relevant education by 2030 .

In the Philippines, the advent of salient reform strategies in policy formulation stirred DepEd to lead institutional reforms in inclusive education. Furthermore, the implementation of the Republic Act (RA) 10533 or the 'Enhanced Basic Education Act of 2013' paved way to a more strategic approach in ensuring relevant education are within the context of Filipino learners. In madrasah education, the DepEd issued Order no. 51 s. 2004 (Standard Curriculum for Elementary Public Schools and Private Madaris) intended to response to the 'rightful and legitimate aspiration for authentic and appropriate Islamic education' (Muslim Education Initiative Review Final Report, 2014, p. 138) of the Muslim-Filipino learners. The aim was to produce Muslim leaners not only acquainted to Islamic knowledge and values but also to enable learners to be productive members of the Philippine society. The notion of multicultural curriculum design (Demir \& Yurdakul, 2015; Guo \& Jamal, 2007; Milligan, 2006) is evident on raising democratic individuals with awareness and acceptance of learners' differences, respect to human rights, and acceptance of other cultures.

\section{Curriculum Proper}

Posner directs the analyst to explore the process of teaching and learning, the different instructional processes, and the over-all purpose of the curriculum in relation to the learning objectives and intended outcomes. In short, curriculum proper is concerned with the purpose and content of the curriculum and its implication. The Refined Elementary Madrasah Curriculum (REMC) for ALIVE program adds two subjects to the regular basic education curriculum: Arabic Language; and Islamic Values. In public school, usually the Arabic language is taught three times a week for 40 minutes and Islamic values education for two times a week. As stipulated on the REMC, the learning goals and competencies aim to develop the learner's knowledge and understanding about Allah and the principles within Islamic faith. The end goal is to prepare the learners to be responsible, competent, and productive Muslim Filipinos whose values are rooted in Islam. Based on the analysis, the subject goals of Arabic Language are keen to 
develop functional literacy in Arabic language. With this, learners are expected to read and understand Arabic upon completion of the program. In addition, there is an attempt to contextualise the learning goals to the Philippine classroom. In Islamic Values Education, the subject goal is to understand the universal values that are found in Holy Qur-an and the Sunnah (tradition) of the Prophet Muhammad anchored to these core values: the 4Ms or Maka-Diyos; Maka-Tao; Maka-Bayan; and Maka-Kalikasan.

The competencies in the curriculum are considered 'a continuity in terms of depth and breadth from grade to grade' (Refine Elementary Madrasah Curriculum, p. 4). This is a characteristic attributed to Spiral Curriculum where key concepts are presented repeatedly to ensure mastery of concepts throughout the curriculum. The RA 10533 or the 'Enhanced Basic Education Act of 2013' prescribed the spiral progression approach to ensure mastery of knowledge and skills after each level. The learning competencies of the Arabic language show progression as the grade level of the learners increases based on the learning expectations the learners are expected to: Grade 1 comprehend on oral fluency knowledge; Grade 2 exemplify listening, speaking, writing, and reading with comprehension at least 4 to 6 syllable words; Grade 3 demonstrate the four basic skills with comprehension of 3 to 4 -word sentences; Grade 4 apply grammar rules properly and correctly; Grade 5 effective communication skills is sought; and Grade 6 assuming mastery of the competencies from the lower to higher grades, the learners are expected to write a simple composition. Considering the expected learning competencies, some of the Asatidz find it challenging on how to teach and translate the lesson objectives into practice effectively and efficiently. Considerably, a significant number of ALIVE teachers being hired are high school graduates in secular education. The REMC is written in English language. However, the Asatidz are expected to be curriculum planners, designers, implementers, and evaluators with awareness of pedagogical practices and content knowledge just like the regular teachers (Sali \& Marasigan, 2020).

The Islamic Values Education's learning expectations are anchored to the core values of $4 \mathrm{Ms}$. The learning expectations vary from different grade levels. In general, from all grade levels, the learners are expected to recite and read certain chapter or Surah (pl. Suwar) based on the assigned chapters of Qur-an and the progression of Prophet Muhammad's life story from early childhood to his early stage of prophethood. Remarkably, in Grade 2 the learners are expected to perform and understand the concept of Salah or obligatory prayers for Muslim. In Grade 3 Ahadith (tradition) are introduced and the five pillars of Islam are presented until 
Grade 6 including the concepts of Zakah (charity), Sawm (fasting), and pilgrimage to Mecca among others.

There are major components of curriculum design: aims, goals, and objectives; content or subject matter; learning experience; and evaluation. However, in the case of REMC, both for Arabic Language and Islamic Values Education despite having the vision, framework describing the core values, and objectives, to include learning competencies; there were no specific learning activities elaborately explaining the instructional strategies and the course resource. Significantly, there was no assessment task or evaluation to measure the results of the curriculum. Ornstein and Hunkins (2018) described the importance of interrelatedness of these basic parts and a 'curriculum's parts should promote the whole' (p. 179).

\section{Curriculum in Use}

In curriculum implementation, the need to consider the physical, cultural, temporal, economic, organisational, political-legal, and personal characteristics are imperative (Posner, 2004). In this category of curriculum analysis, responses from the participants were taken into account to enrich the discussion from the program implementers. The physical factors play a significant role in the teaching and learning process. The Asatidz agreed that viable space for classroom instruction is essential especially on translating the learning competencies into practice. However, only one ALIVE school has its own edifice or classroom and projector for the implementation of the ALIVE program. The rest of the schools have to borrow regular classroom during the weekend. The Asatidz shared their best practices in translating competencies into practice. Most of them employ different instructional strategies such as visual aids, technology-aided instruction, and collaborative activities. In terms of temporal factors, the program conducts face-to-face synchronous class either on weekdays or weekend. The class schedule depends on the arrangement as approved by the school head. However, some Asatidz explained that the 40-minute time allotment is short for an actual classroom instruction. The Asatidz are given monthly stipend as contractual teachers and as curriculum implementers. Most of the time, their stipend are delayed. Some of the ALIVE teachers shared their concerns on physical and temporal factors in the implementation of the REMC:

"Secondly, we can't paste and arrange the devices [instructional materials] in a regular classroom. So what we do, we always bring our devices every 
Saturday because we don't have space to store the materials. (smiling)." P2

"Our biggest problem is classroom (laughing). We are just borrowing regular classroom every Saturday. I hope this will reach the authorities because we are really in need of it." - P3

"The payment [stipend]... Our monthly allowances (duration) are not regular." - P1

Regarding the organisational frame, according to the administrator and madrasah coordinators the ALIVE program is included in the School Improvement Plan and Annual Improvement Plan. However, who to assign as madrasah coordinator at school depends on the school head (e.g. principal), following a certain process of selection. The madrasah coordinator is assigned to make sure the program is implemented at the same time provides mentoring to the Asatidz. Albeit, the madrasah teachers are also encouraged to join the in-service training and DepEd sponsored training for professional development. However, cultural and religious differences are evident as none of the ALIVE coordinators are Muslim or "have indepth knowledge about Islam or even the Arabic language in particular" (Sali \& Marasigan, 2020, p. 208). On cultural factor, interestingly, most of the participants cited several experiences on cultural variances (Sali \& Marasigan, 2020) on the implementation of the program such as low proficiency of mentors on Arabic language. On the other hand, a madrasah coordinator explained the importance of the program as it mainstreams the madrasah education in school and local community of which predominantly non-Muslim. Some of the participants shared their thoughts about the implementation of MEP in their respective schools:

"I was asked by the principal if I am willing to be the [ALIVE] coordinator [madrasah]. I accepted the offer especially now no one is keen to accept it. The task is mostly voluntary." - P6

"Whatever we give to the teachers in regular classes are also given to the madrasah teachers. For instance, school supplies, and everything." - P5

"Included in all school activities [e.g. INSET]. Asatidz are also considered part of faculty/school and family." - P8

Political-legal factors refer to the impact of external organisations have on the curriculum. The ALIVE program is being subsidised by the government through 
the Department of Education. In making sure the madrasah education curriculum is relevant and appropriate to Muslim Filipinos, curriculum development was initiated by DepEd. In 2008 to 2009, a project to review and refine the framework and instructional materials was conducted by DepEd with Southeast Asian Ministers of Education Organization Regional Center for Educational Innovation and Technology (SEAMEO INNOTECH). The Education Department invited Arabic Language and Islamic Studies experts, teachers, and curriculum specialist during the process. In 2010, the finalisation of the framework with vision, subject description, subject goals, learning expectation and competencies and the time allotment were instigated. The institutionalisation of ALIVE program was made possible through series of consultation and efforts of the government and Muslim intellectuals. Also, the different DepEd memoranda support the implementation of the program. As for program sustainability, the use of REMC is guaranteed in the different public schools nationwide.

Posner also directs the analyst to "observe how the official curriculum is translated by teachers into operational curriculum" (Son, Chae, \& Min, 2003, p. 387). In terms of the self-efficacy of the MEP implementer especially the ALIVE teachers, it is imperative to identify different factors that affect their pedagogical practices in implementing the curriculum. Substantially, a significant number of Asatidz being hired are high school graduates in secular education and are not regular teachers. Since, the REMC is written in English language, there are perceived difficulties on the translation of learning competencies making sure the lesson plan is substantial. The Asatidz are expected to perform the tasks of a regular teachers, aside from teaching, they are also curriculum planners, designers, implementers, and evaluators. Furthermore, despite showing diversity in teaching practices, based on the actual classroom observation conducted by Sali (2020b), a significant number of the Asatidz showed disconnect between the lesson objective and the formative assessment chosen to evaluate if the lesson objectives in the curriculum are met. The assessment tasks are given in order to measure or gauge if learning objectives are met. However, in the REMC, there were no explicit assessment tasks anchored on the curriculum. Albeit, there were teaching-learning materials developed by DepEd such as: textbooks; learning guides (for teachers); and other support materials. In addition, the Asatidz find it 'challenging to create a coherent lesson plan with proper alignment where English language is being used for the written output' (Sali, 2020b, p. 128).

The participants explained the importance of student-centred learning as an essential instructional approach to implement the curriculum. Nevertheless, 
there were some challenges faced by the Asatidz on the actual implementation of the instructional plan:

"I have experienced learners from level 1, 2, 3, and 4 in one classroom [multigrade teaching]. One technique that I implemented to level 3 was they should identify the noun or isim. While for level 2, I provided words to read and pronounce correctly. The level 1 will have to follow the lesson on reading while I teach to levels 3 and 2 and inserting techniques for them to also read in their level." - P2

“The books that were distributed had high level [of difficulty] that I think my learners can't grasp in their level. Our learners don't have exposure or experience to madrasah [weekend madrasah]." - P4

\section{Curriculum Critique}

There are numerous strengths and weaknesses identified with the Refined Elementary Madrasah Curriculum. The mainstreaming of MEP in public school has reached more learners in the Philippines. From the perspective of educational consumers, REMC embraces relevant competencies on Arabic language and Islamic Values Education. The curriculum's intention is to equip the learners with competence anchored within their context of accepted cultures, customs, traditions and interests. Also, the curriculum prepares learners to be more competitive and productive members of the society. In addition, the scope and sequence for learning areas have been incorporated within the learning competency matrix. The specified scopes on the different topics give more contexts and guide the Asatidz on the proper pacing in implementing the curriculum. The participants shared that REMC is one of the main differences of non-DepEd affiliated private madaris. In contrary to traditional madrasah, their curriculum is adopted mainly on the country where the administrator had graduated. They don't follow certain competencies as prescribed by the DepEd in ALIVE schools. In the curriculum, the Asatidz are encouraged to utilise other resources or references relevant to the learning competencies prescribed. This approach is not restrictive and allows the curriculum implementers to incorporate relevant resources or learning materials during teaching and learning.

Some of the participants described the curriculum as relevant but not age appropriate especially in Arabic language. In the analysis, for instance the Grade 4 learners are expected to apply grammar rules properly and correctly. To consider, teaching Arabic language to non-natives would require specialised 
teaching skills of the teachers, considering the different student's characteristics, and the feasibility of the program implementation. According to the participants, the competencies being used in the learning resources (e.g. learning resources like books) are too difficult for the learners particularly in higher levels (Grades 3 to 6).

In addition, according to the 2008 Review Report on the Three Years Implementation of ALIVE Program, the response of the teachers in some regions to the Arabic Language textbook for Grades 1 and 2 was 'too difficult and need more appropriate to the grade levels' (p. 47). Also, the Grade 1 pupils experienced difficulty in reading Arabic language used in the textbooks. The teachers agreed that the book was 'too difficult for first time learners and needed revising' (p. 48). In addition, the Muslim Education Initiative Review Final Report (2014) also descriptively discussed the relevance of textbooks and instructional materials as it identified key gaps such as some instructional materials are not within the learning abilities of Muslim learners (Sali \& Marasigan, 2020). The main factor to consider is how to systematically loop the curriculum and the learning resources that is age appropriate and within the grasp of Muslim-Filipino learners.

Significantly, only few madrasah teachers being hired were education graduates. Hence, for most Asatidz they lack Pedagogical Content Knowledge (PCK) (Shulman, 1987) and teaching experience (Darling-Hammond, 2006). Most of the time, their teaching methodologies are adapted from what their previous madrasah teachers of mostly traditional in orientation (Sali, 2020b). Some of the participants explained the importance of having ample class time during teaching and learning process. At present, the daily time allotment or contact hours for the Asatidz in a regular class is 40 minutes. Lastly, one of the main challenges for the program implementers in the translation of curricular competencies is how to come up with a sound lesson plan. Some of the participants find it hard to create lesson plan which is prescribed and expected of them to craft. The limitation of the curriculum is set for Asatidz who are adept in their PCK and especially acquainted to English language.

Aside from the teacher training and professional development to develop teacher effectiveness, according to Sali and Ancho (2021), the Asatidz "perceived teacher's teaching competence as the most essential factor in teaching and learning process" (p. 33). The pedagogical competence comes along with the translation of competencies embedded in the curriculum. Hence, the REMC should also be translated in Asatidz' Mother Tongue or in lingua franca to make it more comprehensible and contextualised for most madrasah teachers. This will ensure efficiency and ease in the implementation of REMC in classroom instruction. In analysing the prescribed learning competencies and its progression in different 
grade levels, it is imperative to judiciously on-board the program implementers to be more aligned with the REMC's vision, goals and objectives.

\section{Significance of the Study in the Development of Madrasah Education in the Philippines}

The implications of the curriculum analysis on REMC identified some salient areas to improve and certain areas to strengthen in the grassroots implementation of MEP. In general, the integration of madrasah education in public school provides an opportunity to ensure the access to quality and relevant education to Muslim Filipino learners. The institutionalisation of Arabic Language and Islamic Values Education (ALIVE) program provides a leeway to mainstream MEP in public schools across the Philippines. The Refined Elementary Madrasah Curriculum was designed based on the series of consultations and efforts of the government and Muslim intellectuals (Sali \& Marasigan, 2020, p. 204). This grassroots approach in curriculum development has been one of the strengths of the REMC.

In addition, the REMC attempts to respond to the social, economic, political, and educational problems through MEP implementation. At present, the DepEd Order no. 41 s. 2017 or the 'Policy Guidelines on Madrasah Education in the K to 12 Basic Education Program' seeks to harmonise existing DepEd issuances on Muslim education. With this, the curriculum perspective of the Refined Madrasah Education Curriculum should provide appropriate and relevant educational opportunities within the context of accepted cultures, customs, traditions and interests.

However, in the program implementation, there are certain areas that need to be reassessed: hiring of the Asatidz; professional development of program implementers; on-boarding of programs; viable learning spaces; and sustainability of MEP. As such, a significant number of Asatidz being hired are high school graduates in secular education. Remarkably, the Asatidz are expected to perform the same tasks as those of a regular teacher. Aside from teaching, the madrasah teachers are also considered as curriculum planners, designers, implementers and evaluators. The leeway to improve and develop pedagogical content knowledge of the program implementers is unprecedented. Also, it is imperative to on-board all the program implementers to be more aligned with the REMC's vision, goals and objectives. In addition, teaching and learning process in various learning institutions implementing ALIVE program should be examined. For instance, there is a dire need to secure viable spaces for classroom instruction in translating the learning competencies into practice as mentioned by most implementers. 
Notably, in the sustainability of MEP implementation, with all the educational challenges encountered, the political-legal aspect provides a salient mechanism to realistically actualise various development efforts in MEP. In the past, the institutionalisation of ALIVE program was made possible through series of consultation and efforts of the government and Muslim intellectuals. The process of grassroots dialogue in relation to curriculum development provides holistic approach in the progress of madrasah education in the Philippines. In general, the success of MEP implementation is tantamount to the efficiency and effectiveness of the grassroots implementation practices.

\section{Conclusion and Recommendations}

The institutionalisation of madrasah education in public school provides an opportunity to ensure access to quality and relevant education among Muslim and non-Muslim learners alike. The Arabic Language and Islamic Values Education program provided a platform to mainstream madrasah education in the public school system. Overall, the Refined Elementary Madrasah Curriculum attempts to provide appropriate and relevant educational opportunities within the context of Muslim Filipino learners. However, there are major components of curriculum design and in the case of the Refined Elementary Madrasah Curriculum (both for Arabic Language and Islamic Values Education), there were no specific learning activities elaborately explaining the instructional strategies and the course resource. In addition, there was no explicit assessment task or suggested evaluation to measure the results of the curriculum. Ornstein and Hunkins (2018) elaborated the importance of interrelatedness of these basic parts in the designing a curriculum.

The curriculum implementers, especially the Asatidz, should be provided with enrichment activities especially in handling multigrade and diverse learners. In addition, mentoring among madrasah teachers should be instigated to strengthen professional learning community in schools. Also, collaborative practices among groups of teachers, especially in reflective inquiry and cooperation in performing professional activities, should be implemented to foster a sense of community in implementing schools are sought.

Furthermore, the grassroots, participatory and collaborative approaches of MEP should continue, particularly in the process of curriculum development. Additionally, the different relevant DepEd memoranda provide program sustainability which guarantees the continuous implementation of MEP in different public schools nationwide. To complement the development efforts of major stakeholders, policy legislation should be strengthened. Lastly, there is also 
a need to revisit the call to restore a top leadership position in DepEd Central Office for sustainability and to further situate madrasah education in the Philippines.

The results of the study provide systematic baseline data in understanding the REMC, which serves as the impetus for future curriculum development of madrasah education in the Philippines. However, this study was limited to three ALIVE schools and the sample size of eight participants during the course of the study. There is a need to explore the different factors that affect the implementation of the curriculum among ALIVE schools: such as school leadership, learner's perspectives on the curricular competencies; assessment and evaluation of student's learning; mentoring practices; self-efficacy; teaching methodologies and pedagogical content knowledge of the madrasah teachers. Lastly, there is a dire need to conduct extensive curriculum mapping to address academic gaps, redundancies, misalignments of the learning competencies vis-àvis to the learning resources provided and most especially its implications on the implementation of ALIVE program in flexible learning situations.

\section{References}

Abu Bakar, M. (Ed.). (2018). Rethinking madrasah education in a globalised world. Abingdon: Routledge.

Abdullah, M. (2018). A pedagogical framework for teacher discourse and practice in Islamic schools. In M. Abdalla., D. Chown, \& M. Abdullah, (Eds), In Islamic schooling in the West: Pathways to renewal (pp. 195226). Cham: Palgrave Macmillan.

Arsad, N. (2007). A framework for integration of madrasah into the basic education (Master's thesis), College of Education, University of the Philippines, Diliman, the Philippines.

Boransing M. B. (2006). Road map to Muslim basic education. Diliman: University of the Philippines.

Caballero-Anthony, M. (2007). Revisiting the Bangsamoro struggle: Contested identities and elusive peace, Asian Security, 3(2), 141-161. https://doi.org/10.1080/14799850701351425

Creswell, J. W. (1998). Qualitative inquiry and research design: Choosing among five traditions. London: SAGE.

Darling-Hammond, L. (2006). Assessing teacher education: The usefulness of multiple measures for assessing program outcomes. Journal of Teacher Education, 57(3), 300-314. https://doi.org/10.1177/0022487105283796 
Demir, L., \& Yurdakul, B. (2015). The examination of the required multicultural education characteristics in curriculum design. Procedia - Social and Behavioral Sciences, 174, 3651-3655. https://doi.org/10.1016/j.sbspro.2015.01.1085

Department of Education, the Philippines. (2011). Order (DO) No. 40, Amendments to DO No. 51, s. 51, s. 2004, or the standard curriculum for elementary public schools and private madaris.

Department of Education, the Philippines. (2017). Order (DO) No. 41, Policy guidelines on Madrasah education in the $\mathrm{K}$ to12 curriculum.

Guo, S., \& Jamal, Z. (2007). Nurturing cultural diversity in higher education: A critical review of selected models. Canadian Journal of Higher Education, 37(3), 28-48. https://doi.org/10.47678/cjhe.v37i3.529

Institute for Autonomy and Governance. (2019). Research on traditional madaris in ARMM and adjacent regions. Cotabato City: Notre Dame University.

Kadi, W. (2006). Education in Islam - Myths and truths. Comparative Education Review, 50(3), 311-324. https://doi.org/10.1086/504818

Lingard, B. (2005). Socially just pedagogies in changing times. International Studies in Sociology of Education, 15(2), 165-186. https://doi.org/10.1080/09620210500200138

Marasigan, A. (2019a), Sustainability concerns of the Madrasah Education Program: Basis for Philippine Islamic and madrasah education policy review. UP CIDS Discussion Paper 2019-10. Quezon City: University of the Philippines, Center for Integrative and Development Studies. Retrieved from https://cids.up.edu.ph/publications/discussion-papers/2019-series/2019$\underline{10 /}$

Marasigan, A. (2019b). Teacher shortage and quality of madrasah education in the Philippines: An analysis of madaris teachers' support system and qualifications. UP CIDS Discussion Paper 2019-09. Quezon City: University of the Philippines, Center for Integrative and Development Studies. https://issuu.com/up.cids/docs/up cids discussion paper 2019-09

Miedema, S. (2006). Public, social, and individual perspectives on religious education. Studies in Philosophy and Education, 25(1), 111-127. https://doi.org/10.1007/s11217-006-6433-z

Merriam, S. B. (2009). Qualitative research: A guide to design and implementation. San Francisco: Jossey-Bass.

Milligan, J. A. (2005). Faith in school: Educational policy responses to ethnoreligious conflict in the Southern Philippines. Journal of Southeast Asian Studies, 36(1), 67-86. Retrieved from https://www.jstor.org/stable/20072629 
Milligan, J. A. (2006). The Islamisation of education. Comparative Education Review Special Issue on Islam and Education, 50(3), 410-430. Retrieved from https://www.journals.uchicago.edu/doi/full/10.1086/503883

Muslim Education Initiative Review Final Report. (2014). Quezon City: Research and Development Foundation of the College of Education - University of the Philippines.

Nunag, D. (1970). The madrasah schools in Marawi City: Their education objectives, practices, and institution societal role (Master's thesis), College of Education, University of the Philippines, Diliman, the Philippines.

Ornstein, A. C., \& Hunkins, F. P. (2018). Curriculum, foundations, principles, and issues. Harlow: Pearson.

Peters, S. (2003). Inclusive education: Achieving education for all. Retrieved from https://www.researchgate.net/publication/228606295

Philippine Statistical Authority. (2015). Retrieved from http://rsso11.psa.gov.ph/article/factsheet-islam-mindanao

Posner, G. J. (1989). Making sense of diversity: The current state of curriculum research. Journal of Curriculum and Supervision, 4(4), 340-361.

Posner, G. J. (2004). Analysing the Curriculum. Boston: McGraw Hill.

Puskás, T., \& Andersson, A. (2019). Keeping Education Non-Confessional While Teaching Children about Religion. Religion \& Education, 46(3), 382399. https://doi.org/10.1080/15507394.2019.1590940

Refined Elementary Madrasah Curriculum. (2010). Manila: Department of Education. Review Report on the Three Years Implementation of ALIVE Program. (2008). Retrieved from https://deped.academia.edu/AsecNoorSaada/Researches

Rodriguez, L. D. (1986). Madrasah General Education Program for Muslim Mindanao (Ph.D. dissertation), Philippine Normal University, Manila, the Philippines.

Sabki, A., \& Hardaker, G. (2013). The madrasah concept of Islamic pedagogy. Educational Review, 65(3), 342-356. https://doi.org/10.1080/00131911.2012.668873

Sali, A. H. A. (2020a). Pedagogical praxis: Muslim-Filipino madrasah teachers' conceptuality of instructional process. IAFOR Journal of Education: Studies in Education, 8(4), 115-131. https://doi.org/10.22492/ije.8.4.07

Sali, A. H. A. (2020b). Pedagogical practices of Asatidz in selected Arabic language and Islamic values education schools in Metro Manila (Master's thesis), Philippine Normal University, Manila, the Philippines. 
Sali, A. H. A., \& Ancho, I. V. (2021). Pedagogical reflections of Muslim-Filipino madrasah teachers: A phenomenological study. Journal of Research, Policy $\mathcal{E}$ Practice of Teachers and Teacher Education, 11(1), 25-39. https://doi.org/10.37134/jrpptte.vol11.1.3.2021

Sali, A. H. A., \& Marasigan, A. (2020). Madrasah education program in the Philippines: An exploratory case study. International Journal of Comparative Education and Development. 22(3), 201-217. https://doi.org/10.1108/IJCED-06-2019-0034

Shulman, L. (1987). Knowledge and teaching: Foundations of the new reform. Harvard Educational Review, 57(1), 1-23. https://doi.org/10.17763/haer.57.1.j463w79r56455411

Solaiman, S. M. (2017). Implementation of Arabic language and Islamic values education (ALIVE) in Marawi City, Philippines: Unveiling the perceptions of ALIVE teachers. Education Journal 2017, 6(1), 38-46. https://doi.org/10.11648/j.edu.20170601.15

Son, Y., Chae, D., \& Min, B. (2003). The analysis of developmental approaches in science, health, and technology (DASH) program using Posner's curriculum model. Journal of Korean Association for Research in Science Education, 23(4), 386-400. Retrieved from https://www.koreascience.or.kr/article/JAKO200317347317467.page

Cite this article (APA):

Sali, A.H.A. (2021). Posner's Curriculum Analysis Framework towards the Development of Philippine Madrasah Education. JATI-Journal of Southeast Asian Studies, Volume 26(1), 163-185

Date Received: 22 February 2021

Date of Acceptance: 19 June 2021 